\title{
INFLUENCES OF THE PURCHASING POWER CHANGE ON THE EVOLUTION OF THE AGROALIMETARY MARKETS ON EUROPEAN UNION LEVEL
}

\author{
Laura Cătălina Țimiraş \\ “Vasile Alecsandri” University of Bacau \\ timiras.laura@ub.ro
}

\begin{abstract}
This paper aims to identify the manifested connection between the dynamics of the population purchasing power and the dynamic of agroalimentary markets in general as well as by product types on European Union level. Based on the last data supplied by Eurostat 2013, using the specific methods for studying the correlations, we have detected that increases and decreases of the purchasing power generated similar changes on agroalimentary markets level from the point of view of achieved sales in most of the poorer countries of the European Union, but not in those states which got beyond the average gross domestic product per capita of the European Union. This relationship has been noticed only on the agroalimentary markets as a whole (respectively on the amounts spent by the population for purchasing agroalimentary goods, beverages and tobacco), but not on the level of markets of various types of product ("meat and meat products", "fruit and vegetables", "dairy produce, eggs and edible oils and fats", "beverages", "sugar and chocolate and sugar confectionery", "tobacco products").
\end{abstract}

\section{Keywords}

agroalimentary markets; sales; economic development; purchasing power; European Union countries

\section{JEL Classification}

M31; O11; C10

\section{The relationship between the purchasing power and the agroalimentary markets evolution}

The population demand for agroalimentary goods is determined by endogenous and exogenous, objective and subjective factors. The main formative element of the demand is the food consumption needs, which are the result of physiological impulses. A determinant of the demand for agroalimentary goods is the household income. The demand for agroalimentary goods being triggered by primary needs is very little elastic to both price and income changes, at least in quantitative terms (except the population who lives at the subsistence level). Income fluctuations (over a certain level that ensures a decent standard of living) lead mainly to qualitative changes on demand (reflected in value indicators). Thus, the economic growth and implicitly the increasing of purchasing power determines the orientation of the population (who has a decent level of living) to more expensive products, with a high level of processing, qualitatively superior, while, in recession times, the decreasing income generates a migration from more expensive products to inferior goods.

Therefore, this paper seeks to find out the reactions of agroalimentary markets - from the point of view of value - in the European Union countries as a result of the general economic expansion / recession and implicitly of the fluctuations in the purchasing 
power, the analysis being based on the latest official statistical data from Eurostat 2013.

\section{The relationship between the purchasing power and the agroalimentary markets evolution on the level of some EU countries after 2000}

The European Union agroalimentary market had an upward trend until 2008 from the point of view of the food, beverages and tobacco sales. Along with the onset of the economic crisis and thus with its impact on the purchasing power, the European agroalimentary market had a fluctuant evolution. The sales evolution in the EU retail market in the period of time 2003-2011 is presented in Table 1.

Table 1 Retail sale of food, beverages and tobacco in specialized stores and nonspecialized stores in 2003-2011 in the European Union (except Croatia)

\begin{tabular}{|c|r|r|}
\hline Year & $\begin{array}{c}\text { Retail sale of food, beverages } \\
\text { and tobacco in specialized } \\
\text { stores } \\
\text { (Millions of Euro) }\end{array}$ & $\begin{array}{c}\text { Retail sale in non-specialized stores } \\
\text { with food beverages or tobacco } \\
\text { predominating } \\
\text { (Millions of Euro) }\end{array}$ \\
\hline 2003 & $120,476.56$ & $743,532.40$ \\
\hline 2004 & $122,791.43$ & $772,512.23$ \\
\hline 2005 & $126,841.90$ & $800,000.00$ \\
\hline 2006 & $130,000.00$ & n.d. \\
\hline 2007 & $136,000.00$ & $900,000.00$ \\
\hline 2008 & $136,000.00$ & $920,832.71$ \\
\hline 2009 & $134,727.58$ & $900,000.00$ \\
\hline 2010 & $136,585.08$ & n.d. \\
\hline 2011 & $134,000.00$ & $900,000.00$ \\
\hline
\end{tabular}

Source: Eurostat, 2013

The wholesale markets of agroalimentary products were also affected by the economic crisis, so we can notice that immediately after 2008 there was a decrease in market size in terms of sales, followed by a slight recovery in the coming years - from 2010 to 2011 (Figure 1).

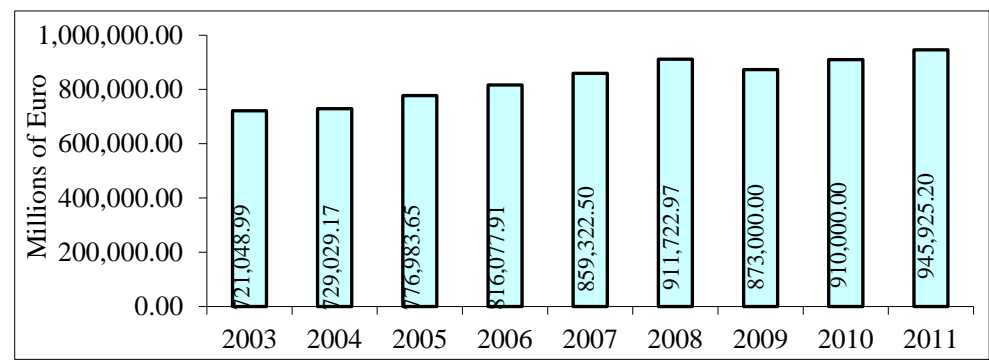

Figure 1 Evolution of wholesale of food, beverages and tobacco on EU level (except Croatia)

Source: Eurostat, 2013 
In almost all EU countries, the dynamics of agroalimentary markets followed the trend registered on community level. Thus, there was a positive trend until 2008 and then, in 2009, the markets experienced an involution, followed by a slight recovery during the next years.

Though along with the onset of the economic crisis the influence of the decrease in the purchasing power on the sales evolution of agroalimentary markets was a direct and immediate one, manifested in almost all the EU countries, we have studied the relationship between the two variables over a longer period of time (2000 -2010), not only for the period that marked the economic crisis. This has been done in order to see whether the connection between the dynamics of purchasing power and the dynamics of agroalimentary markets which has been noticed immediately after the onset of the economic crisis is valid for a longer period of time. Thus, it has been found that the intensity of reactions in agricultural markets as a result of the fluctuations in the purchasing power were different on the level of the EU countries according to their level of development and implicitly to the standard of living of their population. It has been noticed that decreases or increases in the purchasing power were accompanied by similar changes in the agroalimentary markets, especially in the poorest countries of the European Union and only slightly in the countries with a high living standard of the population.

Based on the information presented in the table 2 we can see that on the level of the retail markets, the influences of changes in purchasing power on the evolution of sales of food, beverages and tobacco have been noticed in those countries which are below the average GDP per capita in the EU (23,100 euros / inhabitant in 2010).

Table 2. The corelation between the the dynamics of the retail sales of food, beverages and tobacco and the dynamics of the gross domestic product per capita on the level of European Union countries

\begin{tabular}{|l|r|r|r|r|c|}
\hline \multicolumn{1}{|c|}{ Country } & $\begin{array}{c}\text { Real Gross } \\
\text { Domestic Product } \\
\text { per capita in 2010 } \\
\text { (Euro per } \\
\text { inhabitant) }\end{array}$ & $\begin{array}{c}\text { Value of } \\
\text { correlation } \\
\text { coefficient }\end{array}$ & $\begin{array}{c}\text { Degrees of } \\
\text { freedom }\end{array}$ & $\begin{array}{c}\text { Significance of the } \\
\text { Correlation } \\
\text { value } \\
\text { coefficients for } \\
\text { significance level } \alpha= \\
0.05\end{array}$ \\
\hline Bulgaria & 3,500 & 0.65 & 8 & 2.419 & significant \\
\hline Romania & 4,200 & 0.60 & 8 & 2.121 & insignificant \\
\hline Latvia & 5,900 & 0.84 & 8 & 4.379 & significant \\
\hline Lithuania & 7,100 & 0.81 & 8 & 3.907 & significant \\
\hline Poland & 8,000 & 0.13 & 8 & 0.371 & insignificant \\
\hline Hungary & 8,800 & 0.48 & 8 & 1.548 & insignificant \\
\hline Estonia & 8,300 & 0.65 & 8 & 2.419 & significant \\
\hline Portugal & 14,900 & 0.05 & 8 & 0.142 & insignificant \\
\hline Slovenia & 15,300 & 0.67 & 8 & 2.553 & significant \\
\hline Cyprus & 18,500 & 0.60 & 8 & 2.121 & insignificant \\
\hline Spain & 20,600 & 0.83 & 8 & 4.209 & significant \\
\hline European Union & $\mathbf{2 3 , 1 0 0}$ & & & & \\
\hline Italy & 23,500 & 0.33 & 8 & 0.989 & insignificant \\
\hline France & 27,400 & 0.57 & 8 & 1.962 & insignificant \\
\hline Belgium & 29,600 & 0.78 & 5 & 2.787 & significant \\
\hline Germany & 29,100 & -0.49 & 8 & -1.590 & insignificant \\
\hline United Kingdom & 30,500 & 0.60 & 8 & 2.121 & insignificant \\
\hline Finland & 30,600 & 0.01 & 7 & 0.026 & insignificant \\
\hline Austria & 31,300 & 0.02 & 8 & 0.057 & insignificant \\
\hline Netherlands & 33,100 & 0.02 & 6 & 0.049 & insignificant \\
\hline Sweden & 34,500 & 0.67 & 8 & 2.553 & significant \\
\hline Ireland & 36,500 & 0.52 & 8 & 1.722 & insignificant \\
\hline
\end{tabular}


(Source: personal processing after Eurostat, 2013)

n.d. - no data

Note:

The correlation has been determined based on previous year indexes for the real GDP / capita and cumulative value of retail sale of food, beverages and tobacco in specialized retail stores and nonspecialized in stores with food beverages or tobacco predominating indicators. We have studied those countries wherefore we have had statistical data for the two correlated indicators for the period of time 2000-2010 (2010 being the last year for which official statistic data supplied by Eurostat has been available for Non-specialized retail stores with food beverages or tobacco predominating indicator). For some countries (Belgium, Finland, Netherlands) we have taken into consideration a lower number of years to determine the correlation coefficients according to the available official data.

In order to study the correlation we have determined the Pearson correlation coefficient. The testing for the significance of correlation coefficients has been done using the T test.

Thus, in 6 out of the 11 countries analyzed (50\%) which have a gross domestic product per capita less than 23,100 euros, there have been registered significant correlation coefficients for a significance level of $5 \%$ between the dynamics of sales retail food and beverages and tobacco and the dynamics of GDP per capita, the values of those coefficients denoting medium or strong relations between the two variables studied. Also, analyzing the registered values of the correlation coefficients, we have noticed that only 2 out of the 11 countries (Poland and Portugal) had a very weak connection between the correlated variables.

On the other hand, on the level of the 10 countries analyzed, which have a living standard over the EU average, only two out of them (20\%) had relationships with significant correlation coefficients and in 50\% of them (Germany, Finland, Austria, Netherlands, Italy) the correlation coefficients have attested a very weak, a weak or even an inverse connection between the purchasing power dynamic and the agricultural markets dynamic.

Therefore, it confirms that fluctuations in the purchasing power put their mark on the evolution of agricultural markets, especially in countries where the standard of living is lower (and only accidentally in countries with high living standard).

\section{The relationship between the evolution of the purchasing power and the dynamics of the agroalimentary markets by types of product on the level of some EU countries after 2000}

Having official statistic data on the sales of agroalimentary products by categories only for the wholesale trade, the analysis below is based exclusively on the information concerning this indicator. Given the fact that the agroalimentary products marketed on the wholesale markets are largely distributed on the retail markets and, after that, they get to the final consumer, the trends reflected in the sales evolution on this level can be an indicator for the trends of population demand.

The agroalimentary markets by large groups of product ("meat and meat products", "fruit and vegetables", "dairy produce, eggs and edible oils and fats", "beverages”, "sugar and chocolate and sugar confectionery", "tobacco products") had different trends. For example, in the case of the product markets such as "meat and meat products", "fruit and vegetables", "beverages", along with the onset of the economic crisis we have noticed changes in the positive trends registered until 2008, while on the level of the markets, "sugar and chocolate and sugar confectionery" and "tobacco products", the evolution was upward both before and after the onset of the economic crisis. 


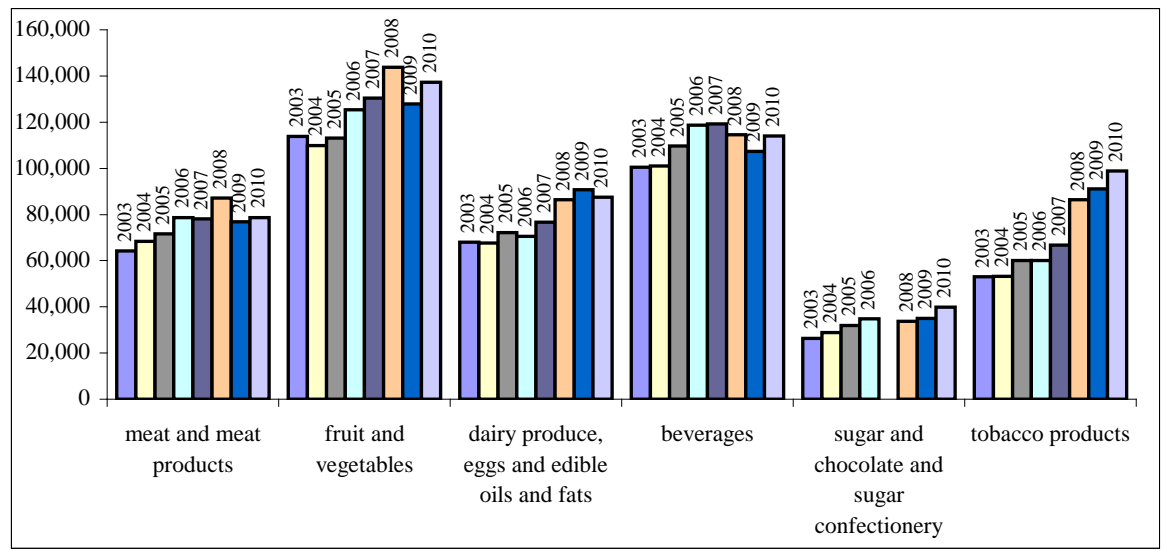

Figure 2 The wholesale evolution by types of agroalimentary products on the EU level (except Crotia) in the period of time 2003-2010 (millions of Euro)

Source: Eurostat, 2013

Studying the relationship between the dynamic of sales by product groups and the evolution of the GDP / capita in the EU countries, we have noticed that, unlike the above-described trends which were registered on the agroalimentary markets level as a whole, we haven't found any influence between the purchasing power dynamic and the dynamic of the sales of agroalimentary products by categories (the correlations registered are insignificant, have low intensity and even different directions). There are a few exceptions - some states where significant correlations have been found (considering a significance level of $5 \%$ ) between the indicators analyzed, but we haven't noticed a manifestation of these connections only in certain categories of countries according to their level of development (Table 3).

The very small number of countries in which the relationship between the variables studied has been verified attests that these are purely coincidental therefore we have been unable to draw any conclusion on how various agroalimentary markets react as a result of the changes in the purchasing power, in general (regardless of the level of development of that country), or by categories of country according to the level of development / purchasing power of their populations.

Table 3. The countries which registered significant correlation coefficients (for a significance level of $5 \%$ ) between the gross domestic product per capita and the wholesale of agroalimentary products by categories

\begin{tabular}{|c|c|c|c|c|c|c|}
\hline \multicolumn{2}{|c|}{ Agroalimetary product categories } \\
\hline $\begin{array}{c}\text { meat and } \\
\text { meat } \\
\text { products }\end{array}$ & $\begin{array}{c}\text { dairy } \\
\text { froduce } \\
\text { vegetables } \\
\text { eggs and } \\
\text { edible oils } \\
\text { and fats }\end{array}$ & $\begin{array}{c}\text { coffee, } \\
\text { tea, } \\
\text { cocoa } \\
\text { and } \\
\text { spices }\end{array}$ & $\begin{array}{c}\text { sugar and } \\
\text { chocolate and } \\
\text { sugar } \\
\text { confectionery }\end{array}$ & $\begin{array}{c}\text { tobacco } \\
\text { products }\end{array}$ \\
\hline $\begin{array}{c}\text { Poland } \\
\text { Hungary }\end{array}$ & $\begin{array}{c}\text { Lithuania } \\
\text { Poland }\end{array}$ & $\begin{array}{c}\text { Lithuania } \\
\text { Hungary } \\
\text { Portugal }\end{array}$ & $\begin{array}{c}\text { Romania } \\
\text { Lithuania } \\
\text { Poland }\end{array}$ & - & $\begin{array}{c}\text { Romania } \\
\text { Hungary }\end{array}$ & Romania \\
\hline
\end{tabular}




\begin{tabular}{|c|c|c|c|c|c|c|}
\hline \multicolumn{7}{|c|}{ Countries with the GDP / capita above the EU average } \\
\hline $\begin{array}{l}\text { United } \\
\text { Kingdom }\end{array}$ & $\begin{array}{c}\text { United } \\
\text { Kingdom }\end{array}$ & - & $\begin{array}{c}\text { United } \\
\text { Kingdom } \\
\text { Netherlands } \\
\text { Sweden }\end{array}$ & - & - & - \\
\hline
\end{tabular}

(Source: personal processing after Eurostat, 2013)

Note:

The correlation has been determined based on previous year indexes for the real GDP / capita and the wholesale of food, beverages and tobacco. We have studied those countries wherefore we have had statistical data for the two correlated indicators for 2000-2010. For some countries we have taken into consideration a lower number of years to determine the correlation coefficients according to the available official data.

In order to study the correlation we have determined the Pearson correlation coefficients. The testing for the significance of correlation coefficients has been done using the $\mathrm{T}$ test.

\section{Conclusions}

In the European Union countries the fluctuations in the purchasing power made their mark on the evolution of the agoalimentary markets from the point of view of the sales, especially in those states where the standard of living is lower than the average of the EU (respectively a GDP / capita under the EU average). Thus, beyond the immediate impact which the decreasing of the purchasing power generated by the economic crisis had on the evolution of the agroalimentary markets in almost all the EU countries, this connection was verified for a longer period of time only in most of poorer countries of the EU.

So, while in the first part of this paper we said that the decreasing of the purchasing power generates an orientation of the population towards cheaper agroalimentary goods and, implicitly the agroalimentary market tends downward from the point of view of value (and not quantity) in those countries with a standard of living which ensures a decent life, however this statement is not valid in the case of countries with a very high standard of living (in this case the agroalimentary markets are not affected by changes in the purchasing power, of course if these changes are not so big as to seriously affect the standard of living) - at least in the countries in question.

We must mention that the influence of changes registered by the purchasing power has been noticed only on the agroalimentary markets as a whole, respectively they affected the total income allotted for the buying of food products (especially in those EU countries where the standard of living is not too high), but not in the various markets by product categories ("meat and meat products", "fruit and vegetables", "dairy produce, eggs and edible oils and fats", "beverages", "sugar and chocolate and sugar confectionery", "tobacco products"), in this last case just a very small number of EU countries, both poorer and richer, registering significant connections between the correlated variables.

\section{References}

Diaconescu, M. (2003), Marketing agroalimentar, Ediţia a II-a revăzută, Bucureşti, Uranus Publishing House.

Eurostat (2013), available on http://epp.eurostat.ec.europa.eu.

Harja E., Țimiraş L.C. (2009), Metode statistice utilizate în cercetarea de marketing, Bacau, Alma Mater Publishing House.

Malhotra, N.K. (2004), Marketing Research an Applied Orientation. Fourth edition, Upper Saddle River, New Jersey, Pearson Education. 
Ţimiraş, L., Nichifor, B., Zaiţ, L. (2012), Particulars of Demand for Agricultural Products in the Domestic Market, International Conference Risk in Contemporary Economy, 243-250.

Ţimiraş, L.C. (2007), Evoluţia marketingului agroalimentar din România, în contextul extinderii Uniunii Europene, Bacau, EduSoft Publishing House.

Voineagu, V., Lilea, E., Goschin, Z., Vătui, M., Boldeanu., D. (2002), Statistică economică. Teorie şi aplicaţii, Bucureşti, Tribuna Economică Publishing House.

Zahiu, L., Dachin, A. (2001), Politici agroalimentare comparate, Bucureşti, Economic Publishing House. 